For citation: Ekonomika regiona [Economy of Region]. - 2016. - Vol. 12, Issue 3. - pp. 755-764

doi 10.17059/2016-3-12

UDC 332.145

JEL R58

T. V. Kushnarenko a), O. A. Chernova ${ }^{\text {b) }}$, L. G. Matveyeva ${ }^{\text {b) }}$

a) Don State Technical University (Rostov-on-Don, Russian Federation)

b) Southern Federal University (Novoshakhtinsk, Russian Federation; e-mail: chernova.olga71@yandex.ru)

\title{
THE PHENOMENON OF MULTICULTURALISM IN THE REGIONAL STRATEGIZING
}

The purpose of the article is to justify the possibility of the modernizing development of the region based on the rational use of the potential of a mixed economy of its territories. In contrast to the existing ideas about multiculturalism as a problem, demonstrating the structural imbalances in the economy of the region, the authors view it as a phenomenon that allows the region to provide a competitive advantage. The methodological base of this study is the convergence of the system, synergistic, institutional and endogenous approaches, and sharing a number of theories - growth poles, territorial industrial clusters, balanced development. The article shows the role of the institutional environment in realizing the potential of a diversified economy in the region. It formulates conceptual positions of the mechanism of regional strategizing aimed at the development of relations between territories with the different types of lifestyles. The basis of the interactions is the consensus of economic interests, compromise of competitive aspirations and market positions of the entities as equal partners. It is concluded that there is the need to change the existing system of regional strategizing in terms of strengthening its focus on the formation of the institutional channels for the communication of corporate, small-scale and farm structures. The recommendations on the potential of the mixed economy of the regions were used in the development of the Strategy of investment development for the Rostov region until 2020.

Keywords: regional strategy, the diversity of the regional economy, economic framework, institutional conditions

\section{Introduction}

The priority of the regional aspect in the management of economic dynamics developed in recent decades in Russia and further updated in the context of the significant changes in the geopolitical and geo-economic framework, defines the methodological and practical importance of clarifying the mechanism of regional strategizing. This involves, first of all, the accumulation of internal, existing regional potential, and an increase of its use in the points and drivers of growth of the real sector of the regional economy. Focus on the non-primary model, modernization, innovation and import substitution in th branches of industrial specialization, both in the short and long-term prospect, means the proper objective of regional resources including the potential of multiculturalism, in the strategic development plans of the regions.

\section{Literature review and methodology of the research}

The methodological base of this study is the convergence of the system, synergistic, institu-

${ }^{1}$ (c) Kushnarenko T. V., Chernova O. A., Matveeva L. G. Text. 2016. tional and endogenous approaches, and sharing a number of theories - growth poles, territorial industrial clusters, balanced development. In Russia, for many years the methodological basis for studying the problem of the mixed economy is the concept of lifestyle as a «type of economic relations, determined by the shape of property, method of menage, methods of coordination of manufacturing and type of regulators of economic relations» [1]. In foreign literature, despite the lack of a clear concept of «lifestyle», there are analogues, which generally convey the meaning of the term: life style, local order, paradigm, etc. - as a particular type of industrial relations [1-3].

Recently, instead of the term «economic order», the term «technological mode» began to be used. A.A. Sitnic considers the technological mode as a form of economic production relations, a form of the combination of the factors of production as a certain level of the development of productive forces on the basis of the dominant production technology with the inherent to this level of economic relations [5] That is, the technological mode is formed around the core and a key factor (technology) that define the system of economic relations and this way of life. V.I. Belousov said that the establishment of 
a certain type of lifestyle provides breakthrough innovations [6].

The term «technological mode» was introduced into scientific circulation by S.Y. Glazyev and D.S. Lions in the development of the theory of long waves by N.D. Kondratiev. The interpretation of S.Y. Glazyev, the technological way is regarded as a set of units that are close in quality characteristics of technology resources and products [7]. However, further he slightly expands the understanding of the «technological way,» paying attention to the meaningful connection of technological structures with the level of institutional development of the national economy, the level of development of the financial system, the scientific sphere, effective realization of economic and social policy [8]. A broader understanding of the category of «lifestyle» is caused by the process of structuring of economic space in the region based on new market and cannot be realized only in the system of industrial relations. S.A. Nikolsky said: «The implementation of transformational processes in the economy implies changes in the whole holistic set of social and economic relations that we find both in production and in the daily life of society, which is a set of system orders» [9]. Thus, the term «lifestyle» is becoming more concise, synthesizing in itself economic, social, technological and even political aspects of the regional system.

\section{Directions of solving the problem and the results}

The historically developed high differentiation of the level and potential of the socio-economic development of Russian regions (Figures 1-5 ${ }^{1}$ makes it impractical to search for new economic realities common to all areas of the country, universal recipes to preserve the integrity, stability, and sustainable growth. More important is the definition of how the regions rational use their competitive advantages relative for unlocking and activation of endogenous capacities at the poles of economic growth in order to effectively participate in national processes, maintain the competitiveness of the Russian economy on the world markets, ensuring food security of the country. Due to objective circumstances, different regions can participate in these processes in accordance with the size of the accumulated potential of competitiveness, but at the same time, it is obvious the importance of involving both central and peripheral areas in this process.

\footnotetext{
${ }^{1}$ Source: Regions of Russia. Socio-economic indicators. (2014) Coll. of articles. Rosstat. Moscow.
}

At the same time, in the context of global strategic goal is to achieve balanced socio-economic development of regions of one macro region, as well as on the scale of the national economy. Therefore, despite the fact that the total number for the whole Russian territory is the model of overtaking modernization, its contents, sectorial priorities, the coverage of the regional economy, and other components can vary significantly even in the same macro-region.

It is caused by, firstly, distinguished multistructuralism of their economies; secondly, by historically formed poles of growth territories that are the drivers of modernization processes; thirdly, by the limited financial resources, involved in innovative projects. At the same time, the strategic goal of modernization means achieving balanced regional development.

In this context, modification of traditional methods of system approach to the management of different level by socio-economic potential and lifestyle macroeconomic system is expressed in a sequential combination of internal factors taking into account the quantitative and qualitative growth with two groups of external factors: macroeconomic and regional accumulating specifics of territorial conditions of their functioning [10].

In accordance with the authors' position, one of the factors activating the potential of different entities of the region is the rational combination of the potential formed over many decades of economic structures. This conclusion is fundamentally important, particularly for the regions of Southern Russia and the North Caucasus, which is characteristic of multiformity and ethnic production in some of them define the profile of these regions. Accounting of the phenomenon of multiculturalism in these regions is particularly important for balanced modernization development, because it implies involvement in these processes not only the center, but also the periphery. Emerging Industry Alliance, bringing together geographically dispersed enterprises of the macro region, are focused on the involvement of all its territories in the modernization process.

The set of new restrictions of global nature, where it is necessary not only to preserve the stability of the Russian macro regions, but also to increase its economic potential, determines the necessity of forming the basis of proximate control of these processes on the basis of the key ideas. It appears that its basic positions are as follows.

1. Considering the relative isolation of macro-regional economic system, as well as the national economy as a whole, in terms of the acceptance of administrative decisions by government. 


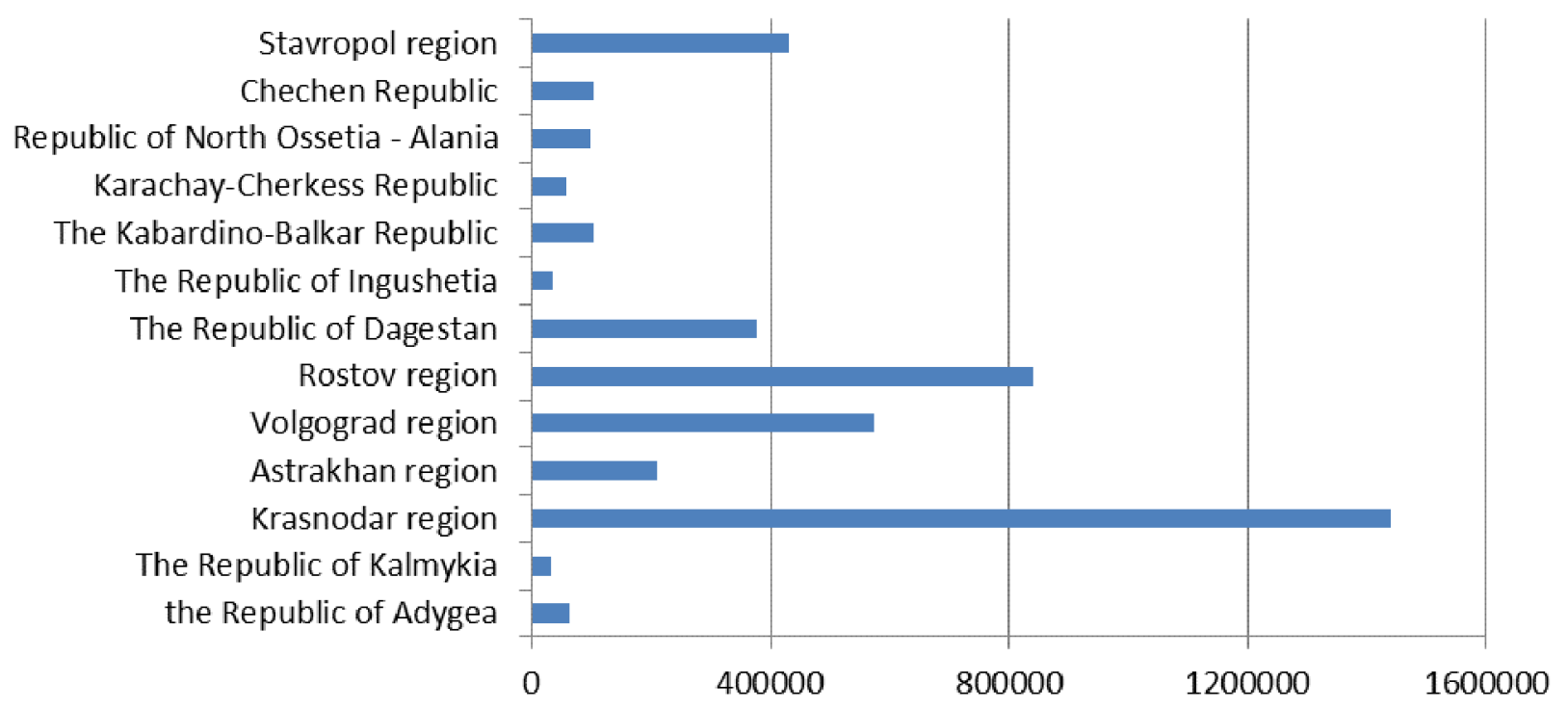

Fig. 1. The gross regional product in the regions of the Southern Federal District and the North Caucasian Federal District, mln rub.

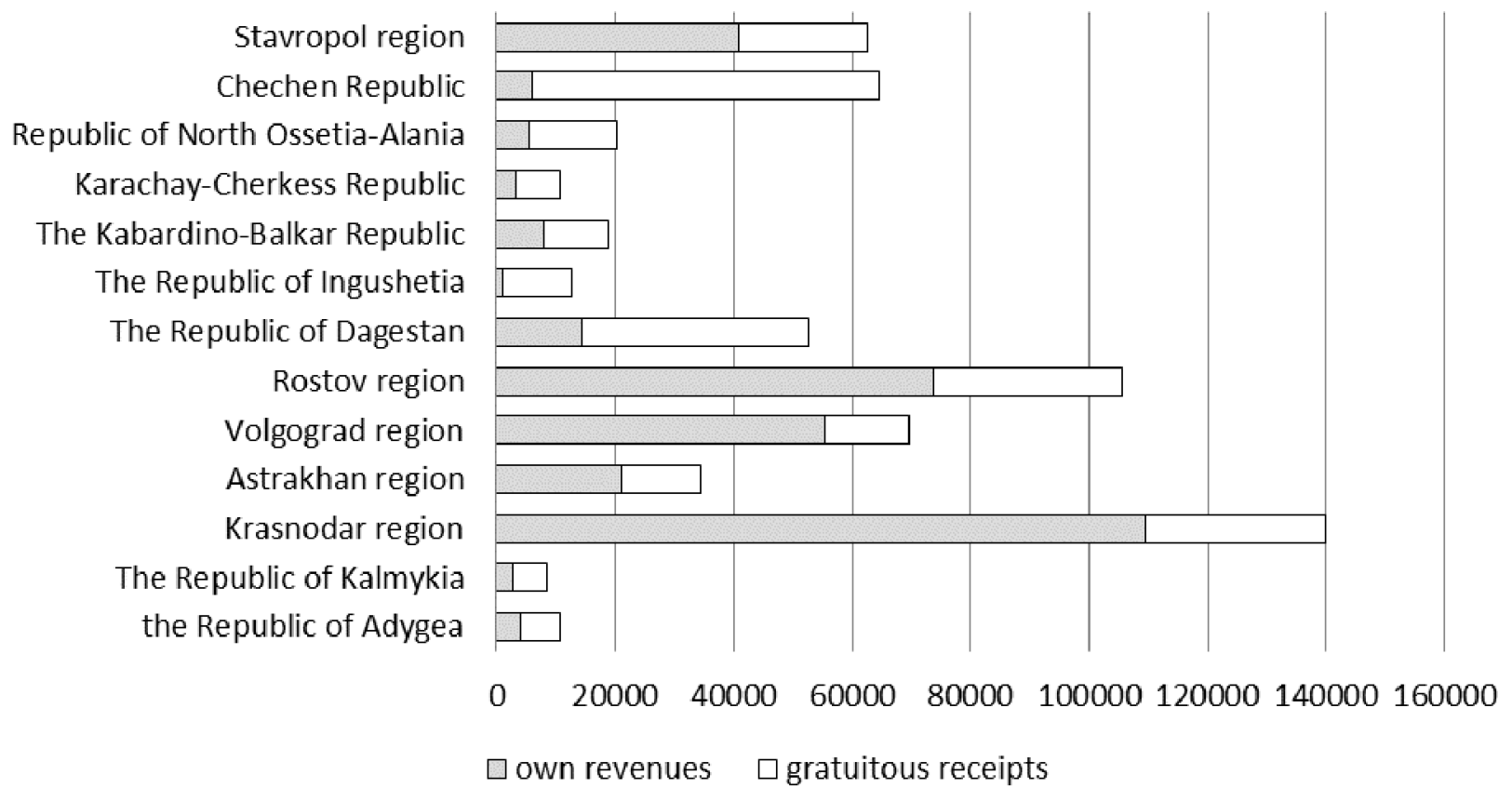

Fig. 2. The consolidated budget revenues SFD and North Caucasus Federal District

2. Concurrent openness to the outside «impacts»-globalization, modernization, innovatization, information, projected from the federal level, which determines the need for adaptation of regional economic policy in order to effectively integrate into the national and global processes.

3. Supporting the development «advanced growth areas», on the one hand, and at the same time the need for a balance involving the potential peripheral areas - on the other hand.

4. Forming an effective institutional framework to support new forms of interaction between the participants of these processes, including inter-regional clusters that involve potential periphery created by the type of virtual consortium for the period of realization of innovative projects.

As one can see, the nature and interaction of the central and peripheral areas of different types of structures, mechanisms and tools used the direction of the strategic interactions determined by the level of institutionalization of relations of participants. At the same time, one of the main problems of the development of integration interactions of territories with different lifestyles is their not only economic, but also institutional heterogeneity. The territories with underdeveloped structures are characterized by inefficient, slow and informal institutions, due to the domination of certain values and social and 


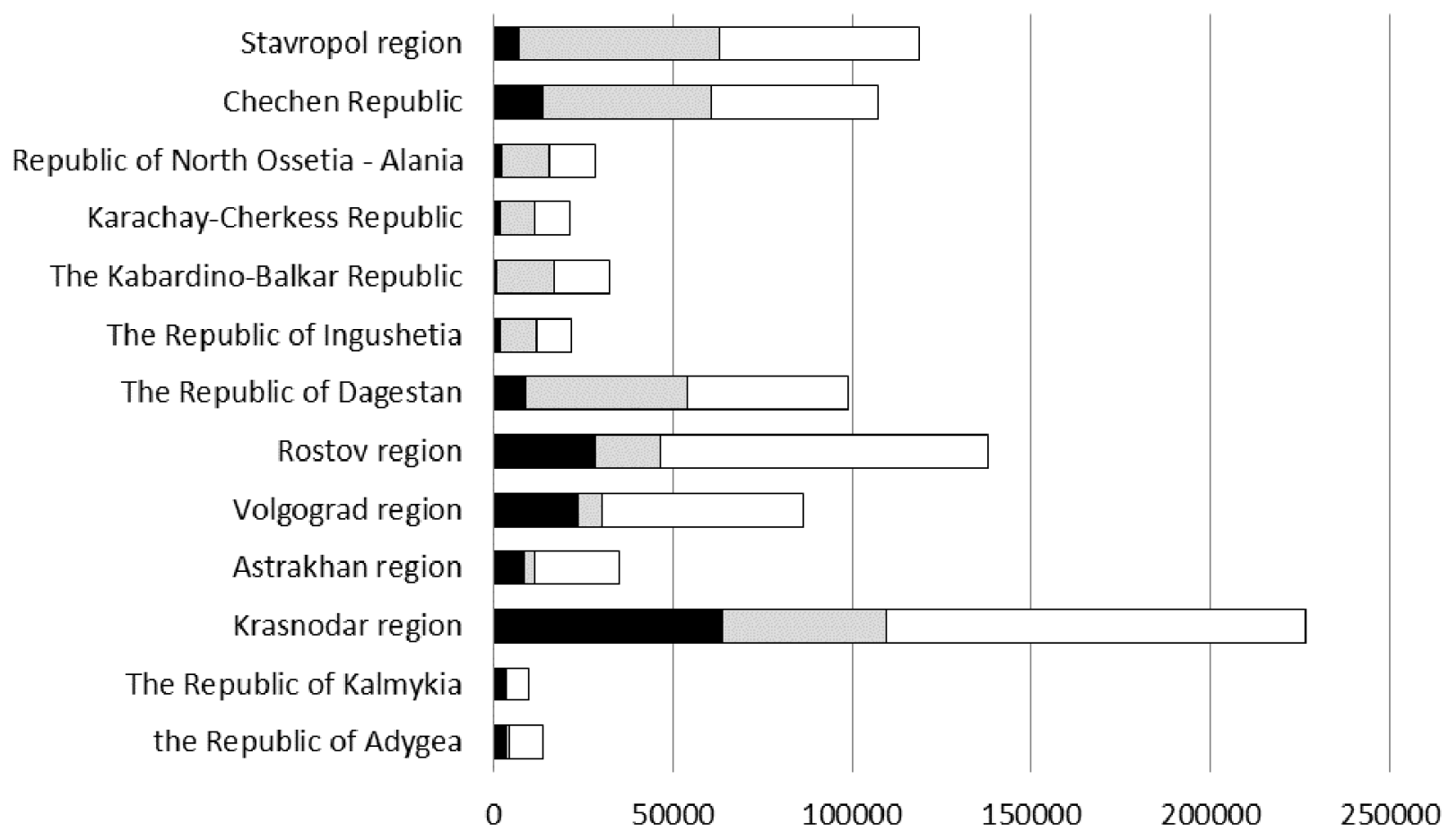

National economy and general government expenditure $\square$ HCS $\square$ Socio-cultural events

Fig. 3. The consolidated budget expenditures SFD and North Caucasus Federal District

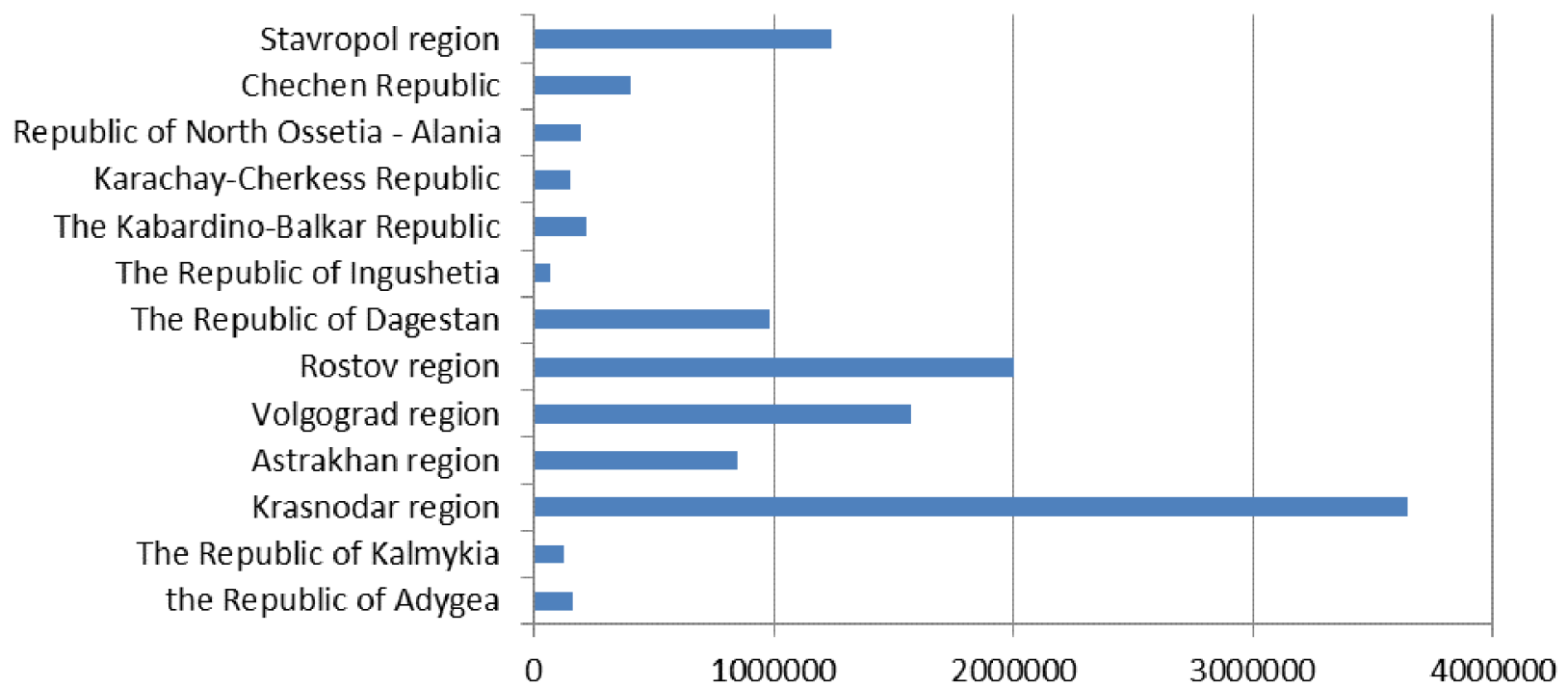

Fig. 4. The fixed assets in the economy of the regions of SFD and the NCFD, mln rub.

economic ties, as well as mechanisms for their implementation.

In this connection, it is interesting to consider the problem of realizing the potential of multiculturalism according to the theory of social capital, which links the concept of «social capital» with the following components: trust; behaviors that facilitate cooperation; social networks [11]. According to V.V. Volchik, under backward lifestyles, they generate institutions (class, caste, nomenclature, etc.) that provide consolidation of certain social roles, which have a kinship, ethnic or religious grounds [12]. Of course, such conditions do not allow and even prevent the transformation of social capital into the resources of modernization. However, radically different relationships are also possible they represent post-capitalist forms of cooperation based on the forms of creative contents of activity and voluntary, free association of the participants of this process. It appears that the development of post-industrial forms of interaction based on the second type of 


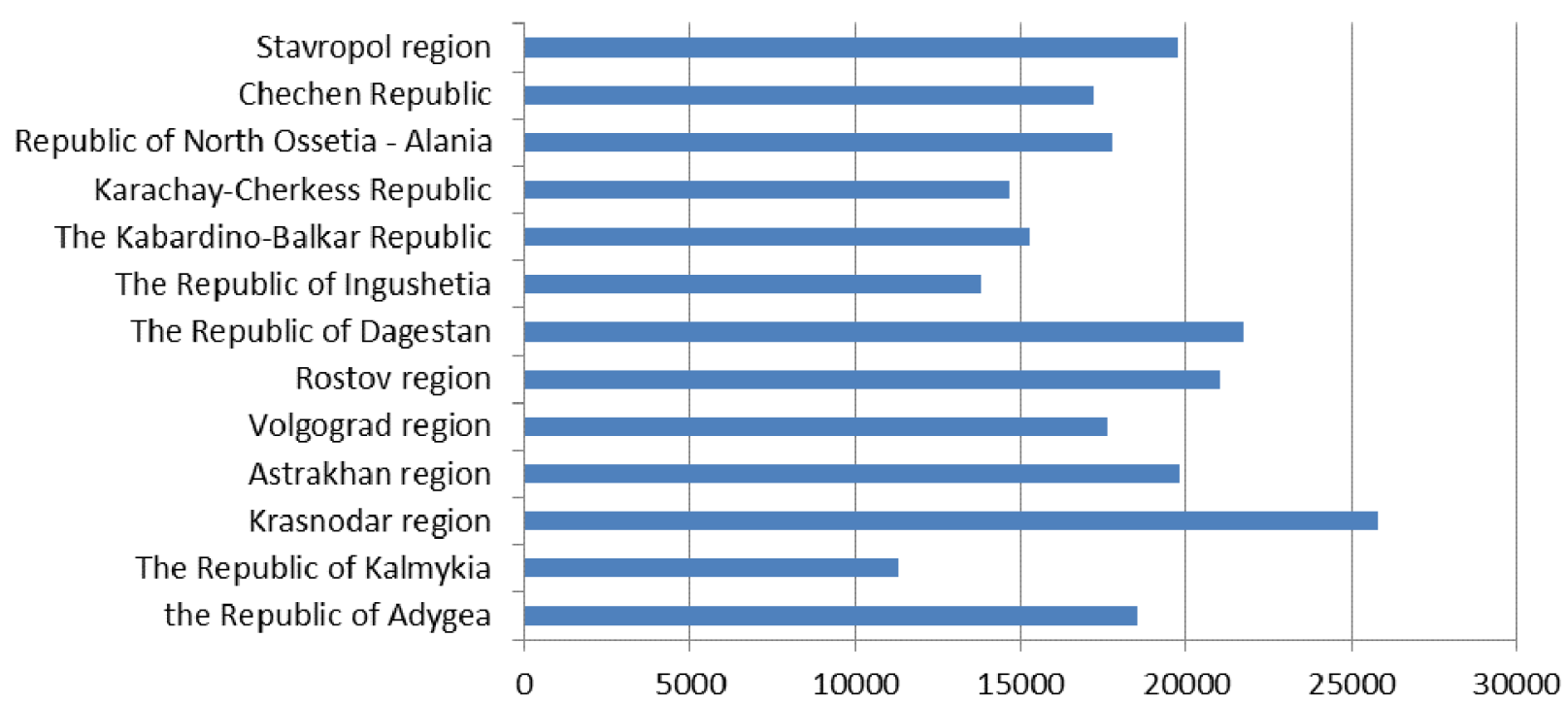

Fig. 5. Average per capita income of the population in the regions of SFD and NCFD, rub.

cooperation is one of the fundamental conditions not only for modernizing of the backward economy of separate territories, but also for the formation of a high-level way of economic development of the macro region as a socio-economic system.

It is unacceptable that formed public and economic institutions emphasized «elitism» of individual types and spheres of activity, limiting the ability to create structures competing with them. However, as the analysis of strategic policy documents shows, the existing policy of industrial development is still not considering the potential integration of various economic structures, which prevents effective institutional changes in the Russian regions. A typical example, in particular, is the conditions for obtaining state support for the formation of innovation clusters. Under these conditions, small and medium-sized enterprises of traditional industries and spheres of activity (usually characterized by low-tech production) on a number of criteria have no chance to be included in the data structure of integration formations. Moreover, the peripheral areas of Southern Russia are subsidized, and individual regional elite has a decisive influence on the direction and volume of financial flows. Consequently, for the formation of the institutional environment implementation of mechanisms aimed at harnessing the potential of multiculturalism must be reflected in the programming documents of regional development criteria of public access territories with different levels of economic structures to innovative projects. It will also create conditions for the modernization of the regional strategy development.

In general, the scheme of formation of the strategic framework of economic development in the region is shown in Figure 6.
Such a representation of the strategic guidelines of regional development is consistent with the vision of the exogenous nature of the institutions when the establishment of certain rules is regarded as an exceptionally strategic process [13], and does not take into account endogenous factors. Of course, institutional changes, particularly with respect to social values and norms of behavior largely have an endogenous nature and are linked not only with the development of industrial relations and with the evolution of behavioral patterns. However, in their discussions on the formation of the institutional environment for the effective realization of the potential of a mixed economy of regions the authors of this article are of the view that exogenous institutional changes, especially those related to the import of the institutions are able to change the current structure of social relations [14-16].

At the same time, to reduce the threat of instability due to the risk dysfunctions of institutions no complementary social values on a given territory, it seems appropriate development of the institute of the strategic researches of problems of socio-economic development of the macro region. Such an institution will determine the potential of the modernization of structural segments of the economy of the region and identify opportunities to increase it at the expense of institutional innovation.

Thus, the system of regional strategy development must undergo significant changes due to the need to realize the potential of multiculturalism to ensure a balanced development of the region's economy for the benefit of the population living on its territory. Presenting a modern tool of regional policy, strategic planning of the territories 


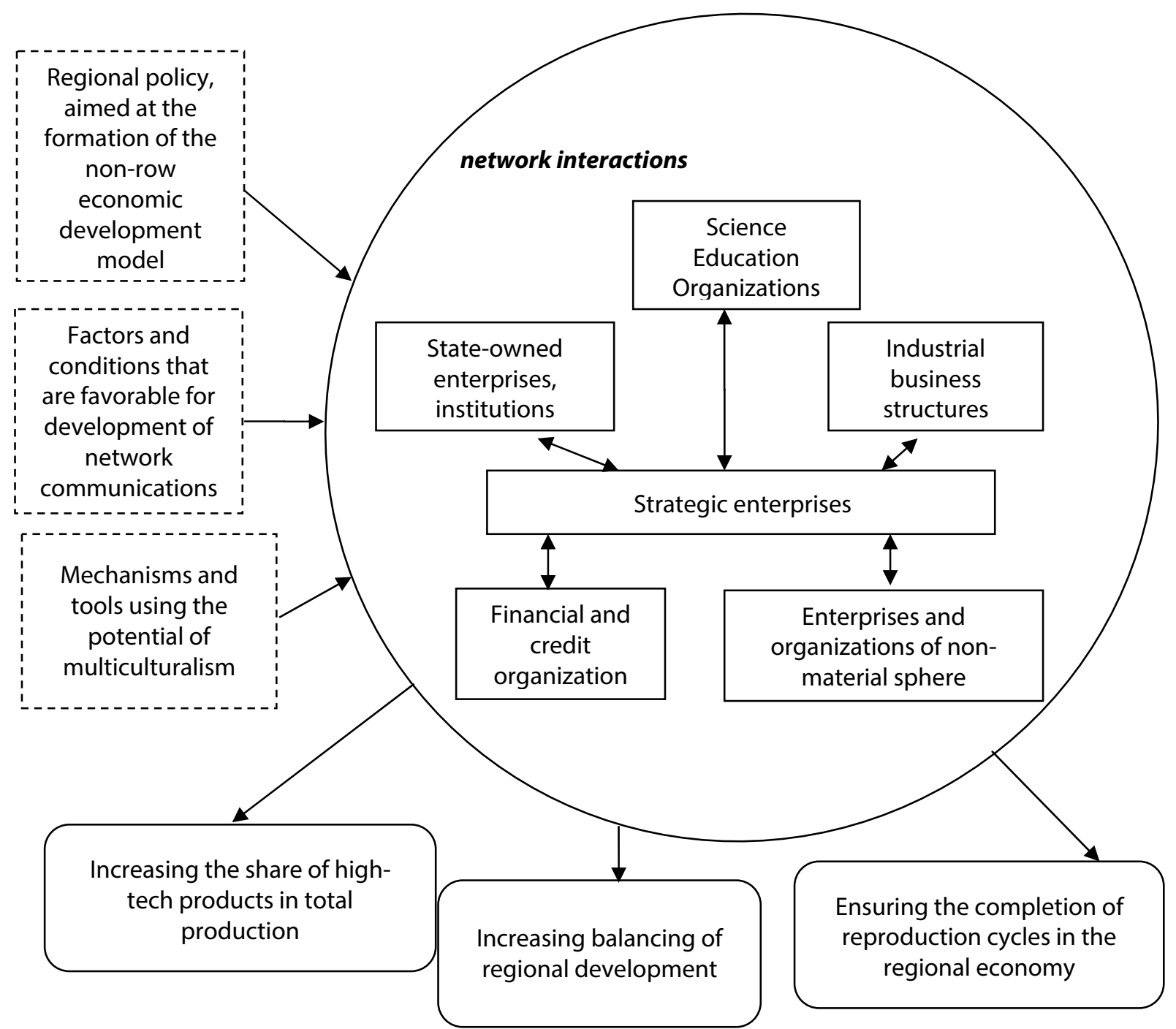

Fig. 6. Scheme of the formation of the strategic framework of the regional economy

should have been further developed in the complex of strategic documents.

In recent years, Russia's regions are increasingly developing the long-term strategy of social and economic development and along with that; they use programs management techniques for priority spheres of the regional economy. The overwhelming number of such strategic documents shows the course of regional economies to innovative development, however the interaction potential of various technological and economic systems which was formed in their existing boundaries for solving the matters on which these documents are oriented, is substantially underutilized, not only in the current, but also in the long-term strategic perspective. Though programming projects are generally focused on the development of the periphery, they have no idea how the problems of the areas with underdeveloped structures will be solved, which mechanisms and technologies will contribute to the implementation of the innovation scenario of their development. Thus, developed strategies do not take into account the full potential of the regions, because they do not imply the implementation of multiculturalism potential of its economy and obtaining synergistic and multiplicative effects.

To increase the strength and stability of the structure of economic skeleton of the territory it is important to make active use of technology, institutions, instruments that have significant potential for integration. Successful in the multiform region can only be the policy of modernization, which is focused on the integration of corporate, small-scale and farm structures, able to create institutional channels of such interaction. In this connection, it is necessary to institutionalize the goals, principles, techniques, mechanisms and instruments for the formation of cluster structures and taking relevant government programs that will ensure the recovery growth and intensifica- 
tion of modernization reforms in the economies of the backward order.

In the System of the regional strategizing structuring of objectives should take into account the potential of complementarity on the territories of the region, taking into account the significant consolidating possibilities of various structures. In this case, it is important to respect the hierarchy of goal setting, based on the relationship of accounting purposes of economic systems and the recognition of the priority objectives of a higher level.

To understand the extent to which the potential of multiculturalism can be used in regional strategy development, it is important to evaluate the resources of modernization of the territory, which have a certain specificity, which is expressed in a variety of economic profile of the region. For example, the specificity of the regional profile of the South of Russia, which defines multistructuralism of its economy caused by the following factors:

- the predominance of small-scale production (about $50 \%$ in the structure of regional economy), as well farms based on family capital (cooperatives, farms, etc.), which is largely due to the agricultural specialization of the region;

- the significant influence of national and cultural values and traditions that form the institutional matrix of economic behavior that is most pronounced in the North Caucasus republics.

In these conditions, it appears that the potential of multiculturalism to a greater extent can be realized in the formation of clusters in the agriculture sphere. In particular, it can be a successful attempt to «enter» into the developing on the basis of the corporate business, such small-scale forms of labor and production as:

- production of goods made of fur, wool and leather;

- manufacture of carpets, felt, processing of sheep and goat wool, knitting wool and downy products;

- cooking homemade cheese, jerky, smoked items;

- gathering and processing of wild medicinal herbs, plants and fruits.

The development of cluster structures in the field of agriculture is even more relevant that in the escalation of economic pressure from world powers decline in imports of food products largely will support domestic producers and increase food safety. At the same time realizing the potential of multiculturalism suggests the need to develop and implement mechanisms to involve potential areas with a low technological way to the formation of innovative clusters. In these circumstances, it seems that the strategy of development of an agro-industrial complex of Southern Russia should be directed to the development of integration «center-periphery» interactions, encouraging cooperation between big business, a different type of industrial economic structure, and small-scale production, including farms.

The mutual benefit of such cooperation should also be noted for both large and medium-tech enterprises and companies of the low technological structure. Large enterprises can test new technologies, new forms of organization of the activity without distracting their assets from main production $[17,18]$. Small business has constant orders and the opportunity to use innovative technology [19]. The region has also some benefits since «upgrading» of business areas with low technological structure reduces interregional asymmetry, the formation of new growth points. Of course, this kind of interaction of large enterprises with businesses of lower technological structures has significant risks arising from the fact that low-tech small enterprises cannot ensure constant positive cash flows, and their goods are often not competitive compared with foreign analogues (in price and quality). Major conditions for reducing business risks and enhancing the functioning of integrated companies in the new economic conditions, characterized by ever increasing competition not only in local but also at regional and global markets is the choice of forms of cooperation which most adequately meet not only the objectives of partner companies, but also the objectives of regional development. This is especially important for companies, organized by the integration of potential of the participants with different types of technological order.

Therefore, in relation to agrarian and industrial complex enterprises, it appears that the organization of interaction between large enterprises on processing agricultural production and small businesses and farms can be carried out by type of interactions in vertically integrated structures (Fig. 7).

Thus, small-scale enterprises and farmers in the technological chain for the production of food will carry out the following steps: preparation of farmland, sowing and fertilizing crops, gathering and transportation of agricultural products. Processing and sorting of products in order to further processing can be carried out by enterprises with higher levels of technological order. Finally, the direct production and sale of the finished products will be carried out by enterprises with a higher level of technologies. 


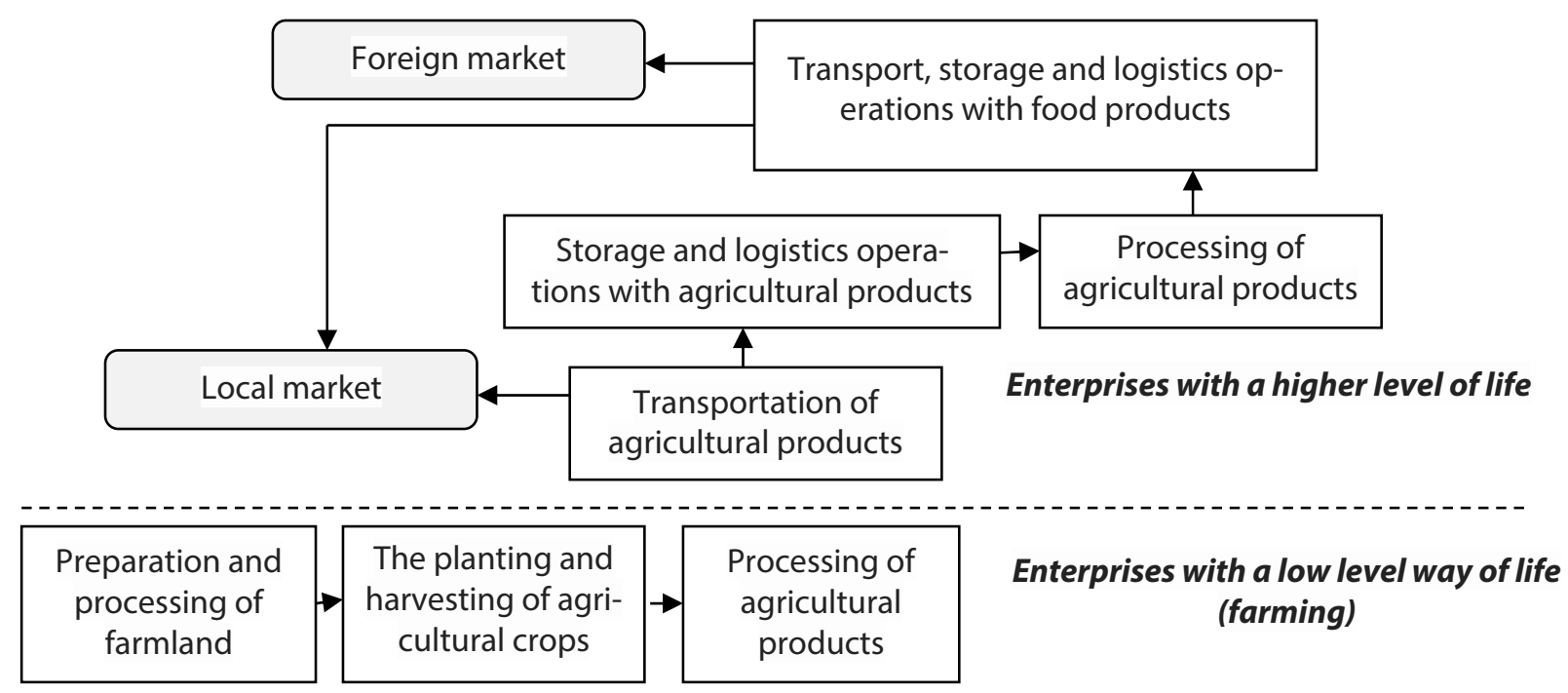

Fig. 7. Scheme of interaction of the enterprises for the production and processing of agricultural products

Should be noted that integration and interaction are possible between close on type of technological order (the same order) subjects. This type of integration involves a strategic alliance between competing manufacturers [20]. Even in cooperation of enterprises with low technological structure, such cooperation can bring tangible benefit by combining competent professionals and innovative developments. These strategic alliances can be implemented in the form of alliances based on the partial integration: cooperation for the production of individual components of the final product, different at competing producers (packaging, food, fertilizers and so on.).

Thus, improving the efficiency of the regional strategy development can be achieved by realizing the potential of a regional system of multiculturalism by including the structure of the cluster geographically adjacent industries, interconnected companies and institutions of different economic orders.

The effectiveness of the cluster, as well as the entire regional system, is directly determined by the possibilities of real production, as well as the nature and frequency of interactions of individual subjects. Practice shows that in a competitive economy, a significant, if not dominant, part of the small agricultural enterprises somehow is in the sphere of interests of big companies. Thus, stable position, profits, financial and investment opportunities in small-scale and subsistence production is directly dependent on the nature of interactions with large enterprises.

Small businesses with low technological structure should be part of the production structure of large enterprises, which can use their potential for innovative development. Large companies should be interested in working with small businesses simply because such cooperation compensates their sluggishness in finding and implementing new technical and organizational solutions, allows concentrating capital in breakthrough areas. The integration of small agricultural enterprises with large agricultural processing companies will not only promote balanced regional development but also the implementation of state policy of import substitution. Obvious that in this regard, it is necessary to boost co-operation of small and large agricultural enterprises, considering the process as the main direction of formation of the non-resource model of the national economy.

In this context, the further development of the regional strategy development should take into account the following points:

- the need for a gradual displacement of the state's role in the formation of clusters by supporting self-organizational trends such as generic operational structure-forming and non-resource bases of the development of the region;

- the development cooperation of local industrial groups with scientific and educational institutions for the formation of innovative production chain at all stages of the production process;

- the formation of intercluster interactions promoting the realization of innovative «interdisciplinary» projects, including cross-border nature.

To sum up the above, we can say that the system of regional strategy development must undergo significant changes due to the need to realize the potential of multiculturalism to ensure a balanced development of the region's economy for the benefit of the population living on its territory.

\section{Conclusions}

The results of the research of the problem of multiculturalism accounting on Russian territo- 
ries in the regional strategy development indicate that the basis for constructing interactions of the regions with different structure must be the consensus of economic interests, the compromise of competitive aspirations and the market positions of economic entities that enter into relationships with each other as equal partners. To improve the efficiency of these interactions, it is necessary to eliminate institutional barriers preventing the flow of resources of modernization into backward areas. Thus, it is necessary to identify a number of large-scale strategic tasks, which involve changes in the system character in the frames of the program and purpose approach to the formation of regional economic policy directions:

- flexible institution «binding» of modernization resources modernization of the regions with different types of lifestyles with the purpose of innovative development of the real sector;
- the development of modern infrastructure of interaction among economic entities of different types of technological structures;

- formation of regional innovation and industrial clusters with the involvement of territories with different modes into their structure;

- overcoming institutional deficits, creating a competitive environment for the development of partnership among the participants of integration structures.

The tools for the implementation of these directions should be target development programs (federal, regional, sectorial). In that connection, the further development of the work on regional strategy development is necessary where the key priority is to develop mechanisms to realize the potential of multiculturalism of territorial economies and their integration in the process of modernization of the macro region economy.

\section{References}

1. Popov, A. I. (2006). Ekonomicheskaya teoriya [Economic theory]. St. Petersburg: Piter Publ., 544.

2. Karnaukhova, O. (2012). Ethno-Cultural Clusters and Russian Multicultural Cities: The Case of the South Russian Agglomeration. Journal of Contemporary European Studies. Retrieved from: http://www.researchgate.net/publication/235561668_Ethno-cultural_Clusters_and_Russian_Multicultural_Cities_The_Case_of_the_South_Russian_ Agglomeration (date of access: 3.06.2016).

3. Moulaert, F. \& Mehmood, A. (2010). Analysing regional development and policy: A structural-realist approach. Regional Studies, 44(1), 103-118.

4. Perez, C. (2011). Techno-Economic Paradigms. In: W. Drechsler et al. (Eds). London: Anthem Press, The Other Canon Foundation, 442.

5. Sytnik, O. A. (2011). Osobennosti razvitiya novogo tekhnologicheskogo uklada [Features of development of a new technological paradigm]. Saratov: Nauka Publ., 152.

6. Belousov, V. I. \& Belousov, A. V. (2010). Problemy postkrizisnoy modernizatsii rossiyskoy ekonomiki [Problems of post-crisis modernization of the Russian economy]. Problemy sovremennoy ekonomiki [Problems of modern economy], 2(34), 19-21.

7. Glazyev, S. Y. (1993). Teoriya dolgosrochnogo tekhniko-ekonomicheskogo razvitiya [Theory of long-term technological and economic development]. Mezhdun. Fond Kondratyeva [Intern. Fund N. D. Kondratieff]. Moscow: Vladar Publ., 310.

8. Glazyev, S. Y. (2015). Politika perekhoda k effektivnoy ekonomike [Politics of transition to an efficient economy]. Sergey Glazyev. Retrieved from: http://www.glazev.ru/econom_polit/353/ (date of access: 3.06.2016).

9. Nikolsky, S. A. (2001). Agrarnaya ekonomika, selskaya obshchnost i problema sotsialno-ekonomicheskikh ukladov [Agricultural Economics, rural community and the problem of socio-economic systems]. Voprosy filisofii [Problems of philosophy], 12, 16-27.

10. Matveeva, L. G. \& Chernova, O. A. (2013). Modelirovanie protsessov upravleniya resursnymi potokami v tselyakh razvitiya periferiynykh territoriy [Modeling of management processes and resource flows for development of peripheral areas]. Terra Economicus, 11(3-2), 84-88.

11. Polishchuk, L. \& Menachem, R. (2011). Ekonomicheskoye naznachenie sotsialnogo kapitala [Economic purpose of social capital]. Voprosy ekonomiki [Problems of economics], 12, 46-65.

12. Volchik, V. V. \& Kot, V. V. (2013). Institutsionalnyye izmeneniya v periferiynykh regionakh grazhdanskikh institutov [Institutional developments in peripheral regions of civil institutions]. Terra Economicus, 11(4), 12-35.

13. Brousseau, E., Garrouste, R. \& Raynaud, E. (2011). Institutional changes: Alternative theories and consequences for institutional design. Journal of Economic Behavior and Organization, 79(1-2), 3-19.

14. Benneworth, P. \& Rutten, R. (2011). Territorial innovation models beyond the learning regions: towards understanding the social dynamics of innovation networks. 16th International Conference of the Regional Studies Association, Newcastle upon Tyne, United Kingdom, 18th-20th April 2011. Retrieved from. http://www.regionalstudies.org/uploads/conferences/ presentations/international-conference-2011/benneworth.pdf (date of access: 3.06.2016).

15. Wallis, J. J. (2011). Institutions, organizations, impersonality, and interests: The dynamics of institutions. Journal of Economic Behavior and Organization, 79(1-2), 48-64.

16. Dementyev, V. V. (2013). Some peculiarities of the subject of the institutional theory. Journal of Institutional Studies, 5(3), 5-13. 
17. Caniels, M. C. \& Romijn, H. (2003). Agglomeration Advantage and Capability Buildingin Industrial Clusters: The Missing Link. The Journal of Development Study, 39(3), 129-154.

18. Ingstrup, M. B., Freytag, P. V. \& Damgaard, T. (2009). Cluster initiation and development: A critical view from a network perspective! Conference at Euromed Management. 2009. France. Retrieved from: http://www.impgroup.org/uploads/papers/6917.pdf (date of access: 3.06.2016).

19. Mensch, G. (1979). Stalemate in Technology - Innovations Overcome the Depression. New York, NY: Ballinger, 241.

20. Oliveira, J. A. \& Ali, S. H. (2011). Gemstone mining as a development cluster: A study of Brazil's emerald mines. Resources Policy, 36, 132-141.

\section{Authors}

Tatiana Vladimirovna Kushnarenko - PhD in Agriculture, Associate Professor, Head of the Chair of Accounting, Financial Analysis and Audit, Don State Technical University (1, Gagarina Sqr., Rostov-on-Don, 344010, Russian Federation; e-mail: chernovaolga71@mail.ru).

Olga Anatolyevna Chernova - Doctor of Economics, Associate Professor, Professor, Department of Information Economy, Southern Federal University (88, Gorkogo St., Rostov-on-Don, 344082, Russian Federation; e-mail: chernova. olga71@yandex.ru).

Lyudmila Grigoryevna Matveyeva - Doctor of Economics, Professor, Head of the Department of Information Economy, Southern Federal University (88, Gorkogo St., Rostov-on-Don, 344082, Russian Federation; e-mail: matveeva_lg@mail.ru). 